Claremont Colleges

Scholarship@ Claremont

Library Staff Publications and Research

Library Publications

$1-1-2011$

\title{
Making E--serials Holdings Data Transferable: Applying the KBART Recommended Practice
}

Jason S. Price

Claremont University Consortium

Lori Duggan

Indiana University - Bloomington

\section{Recommended Citation}

Price, J.S. and L. Duggan (2011) Making E-serials Holdings Data Transferable: Applying the KBART Recommended Practice. The Serials Librarian 60(1-4):229-233 http://dx.doi.org/10.1080/0361526X.2011.556039

This Article is brought to you for free and open access by the Library Publications at Scholarship @ Claremont. It has been accepted for inclusion in Library Staff Publications and Research by an authorized administrator of Scholarship @ Claremont. For more information, please contact scholarship@cuc.claremont.edu. 


\title{
Making E-serials Holdings Data Transferable: Applying the KBART Recommended Practice Jason Price, Presenter Lori Duggan, Recorder
}

\begin{abstract}
The Knowledge Bases and Related Tools (KBART) project is an initiative of the National Information Standards Organization (NISO) and UKSG which has established a set of best practices for the exchange of electronic resource holdings metadata between content providers and knowledgebase developers. The benefits of KBART are that it relieves information professionals from the time consuming process of actively reconciling electronic journal title lists, and addresses the many inadequacies which are common in title holdings lists. As of June 1, 2010, KBART has been endorsed by American Institute of Physics, Ex Libris, Serials Solutions and OCLC. Information professionals can facilitate the further endorsement of KBART by requesting accurate holdings lists from providers up front and referring providers to the KBART recommendations to encourage broader adoption of these best practices. Looking forward, the KBART Working Group hopes to achieve universal acceptance of these best practices and the expansion of the practice to more varied electronic resource formats.
\end{abstract}

Keywords: Knowledge Bases and Related Tools (KBART), National Information Standards Organization (NISO), UKSG, metadata, holdings list, knowledgebase, openURL 


\section{Introduction}

Jason Price is currently a member of the Knowledge Bases And Related Tools (KBART) Working Group which is now entering its second phase of the development process. In this presentation, Jason provided background on the KBART project, the issues this project is intended to address, and shared the current status and latest developments of the project. Jason also offered ways in which information professionals can work to move KBART towards broader acceptance, and provided a vision for the future of the KBART project moving forward.

\section{Overview of KBART}

KBART is an initiative of the National Information Standards Organization (NISO) and UKSG to explore the use of OpenURL to provide solutions to the various data problems existing in the knowledgebase supply chain. ${ }^{1}$ In addition to these two standards organizations, the KBART Working Group, consisting of knowledge base vendors, content aggregators, publishers, subscription agents, libraries and consortia, came together to examine the prevailing issues and develop a recommended practice. ${ }^{2}$ Price described KBART as a set of practical recommendations for the timely exchange of accurate metadata between content providers and knowledgebase developers, a universally acceptable holdings list format, and a single solution for sharing holdings data across the scholarly content supply chain. The knowledgebase is at the center of this supply chain, with content originating from the publisher, moving through the chain and ultimately being delivered to users via an institutional discovery tool (Figure 1). 


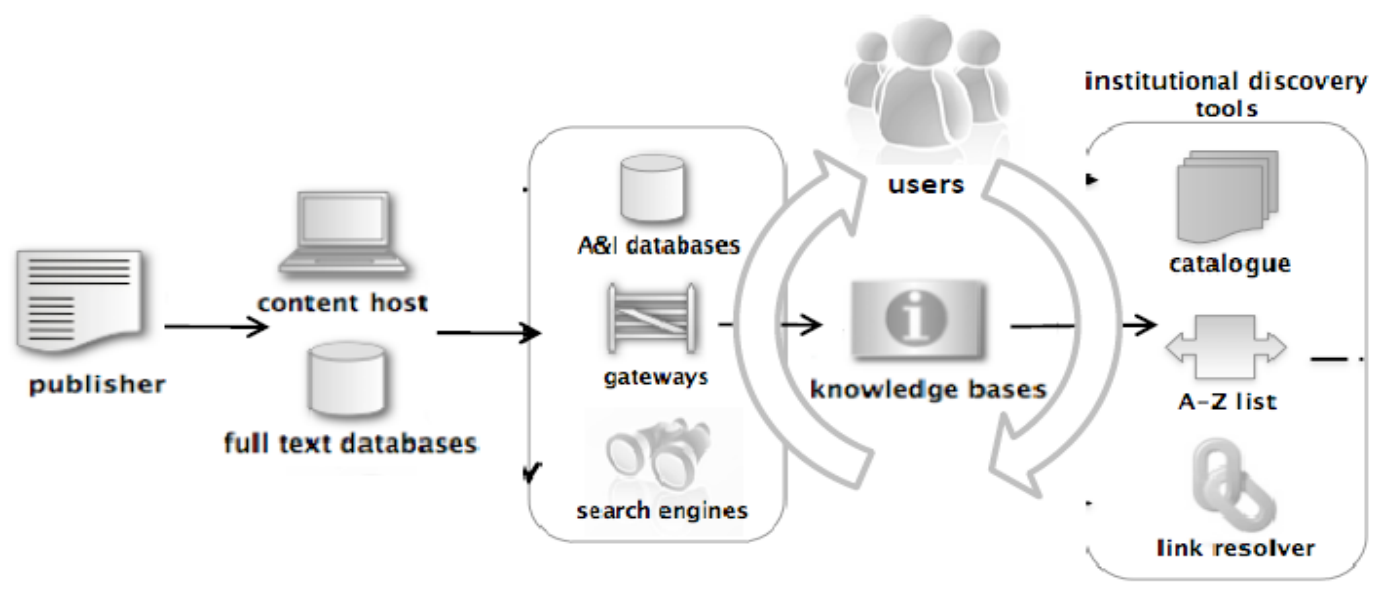

Figure 1 Information Supply Chain

Knowledgebase management without the benefit of KBART includes the proactive reconciliation of an ejournal package lists by information professionals at the library, consortium and knowledgebase provider level, which is a time and labor intensive process. One of the advantages of KBART is that it enables the maintenance of accurate package content coverage data by supporting openURL link resolvers, supporting ejournal MARC record delivery services, and enabling automated updating by knowledgebase providers. Another benefit is that KBART addresses common holding list inadequacies including the re-use of ISSN numbers, embargo period ambiguities and inconsistent date and enumeration formats. The impact of KBART is that it will essentially put an end to information professionals serving as translators for this data as the list of necessary title list elements is standardized and automatically ingested into the knowledgebase (Figure 2). 


\begin{tabular}{|l|l|}
\hline publication_title & Publication title \\
\hline print_identifier & Print-format identifier (i.e., ISSN, ISBN, etc.) \\
\hline online_identifier & Online-format identifier (i..e, elSSN, elSBN, etc.) \\
\hline date_first_issue_online & Date of first issue available online \\
\hline num_first_vol_online & Number of first volume available online \\
\hline num_first_issue_online & Number of first issue available online \\
\hline date_last_issue_online & $\begin{array}{l}\text { Date of last issue available online (or blank, if } \\
\text { coverage is to present) }\end{array}$ \\
\hline num_last_vol_online & $\begin{array}{l}\text { Number of last volume available online (or blank, if } \\
\text { coverage is to present) }\end{array}$ \\
\hline num_last_issue_online & $\begin{array}{l}\text { Number of last issue available online (or blank, if } \\
\text { coverage is to present) }\end{array}$ \\
\hline title_url & Title-level URL \\
\hline first_author & First author (for monographs) \\
\hline title_id & Title ID \\
\hline embargo_info & Embargo information \\
\hline coverage_depth & Coverage depth (e.g., abstracts or full text) \\
\hline coverage_notes & Coverage notes \\
\hline publisher_name & Publisher name (if not given in the file's title) \\
\hline
\end{tabular}

Figure 2 KBART Metadata Exchange Format

\section{Current Status of KBART}

The KBART working group has completed Phase I of the project, which focused on best practices for addressing existing data problems affecting the supply chain of information for knowledgebases. The Phase I Recommended Practice report was published in January 2010, and KBART is currently a NISO/UKSG recommended practice. ${ }^{3}$ The Working Group is now entering Phase II of the project which will focus on adoption of the Phase I recommendations. As of June 1, 2010, KBART has been publicly endorsed by American Institute of Physics, Ex Libris, Serials Solutions and OCLC. ${ }^{4}$ Price encouraged librarians and information professionals to become involved in the adoption of KBART by lobbying publishers for delivery of usable holdings lists before making the purchase, and directing publishers to KBART when these holdings lists prove to be inadequate. Price also indicated the following steps publishers can take to adopt the KBART best practices: 
- Review the requirements for transitioning to KBART compliance ${ }^{5}$

- Format ejournal and ebook content availability data to meet the requirements

- Self check your datasheets(s) on the KBART website to ensure that they conform to the recommended practice and make any necessary corrections

- Ensure that you have a process in place for regular data exchange at outlined in section 5.2 of the KBART report

- Register your organization on the KBART registry website, providing a link to download the newly KBART formatted dataset(s) ${ }^{6}$

\section{Future Directions}

The vision beyond KBART is to achieve universally accepted standardized publisher metadata with the KBART registry in place in order for libraries to realize the benefit of the information being regularly distributed and available on demand. Another big push will be broad adoption of the practice and more extensive content type coverage, such as ebooks and conference proceedings. Finally, there has been discussion within the KBART working group regarding the distribution of metadata which has been customized for consortia and institution level access lists based on what is accessible from a particular IP address. Price indicated that while this final goal may be more of a dream on his part, this would ensure that access lists are customized for individual institutions rather than a global list, resulting in an accurate account of what titles for which the institution has actually purchased. The KBART Working Group will continue to convene regularly to achieve the realization of this vision. 


\section{Notes}

1. UKSG, “KBART: Knowledge Bases And Related Tools Working Group," http://www.uksg.org/kbart (accessed June 29, 2010).

2. UKSG, "KBART Working Group Members," http://www.uksg.org/kbart/members (accessed June 29, 2010).

3. UKSG, "KBART 1.0: Summary of Recommendations," http://www.uksg.org/kbart/s1/summary (accessed June 29, 2010).

4. UKSG, "KBART: Endorsing Organizations," http://www.uksg.org/kbart/endorsers (accessed June 29, 2010).

5. UKSG, "KBART 5.1: Transitioning to KBART," http://www.uksg.org/kbart/s5/transition (accessed June 29, 2010).

6. NISO, UKSG, “KBART Registry," http://bit.ly/kbartregistry (accessed June 29, 2010)

\section{Contributor Notes}

Jason Price is the Science and Electronic Resources Librarian with the Libraries of the Claremont Colleges in Claremont California and is a member of the Knowledge Bases and Related Tools (KBART) Working Group.

Lori Duggan is the Head of Electronic Resources at Indiana University Libraries. 